\title{
UJI AKTIVITAS ANTIMIKROBA DARI JAMUR LAUT YANG BERASOSIASI DENGAN ORGANISME LAUT KARANG LUNAK Lobophytum sp.
}

\author{
Yuni Irianty Katili' ${ }^{1)}$, Defny S. Wewengkang ${ }^{1)}$, Henki Rotinsulu ${ }^{1)}$ \\ Program Studi Farmasi FMIPA UNSRAT Manado, 95115
}

\begin{abstract}
Soft coral (Octocorallia alcyonacea) is an animal were member of Coelenterata that live in tropical and subtropical shallow marine waters. Soft corals have considerable potentially in producing active compounds that can be used in the pharmaceutical world. This study aims to determine the antimicrobial activity of marine mushrooms associated with soft coral Lobophyton sp., against Staphylococcus aureus, Eschericia coli and Candida albicans. The results of this study indicate that extracts from fungi associated with soft coral Lobophyton sp., have activity only in Staphylococcus aureus and Candida albicans, whereas for Eschericia coli have no antimicrobial activity.
\end{abstract}

Keywords: Antimicrobial, Sea Mushroom, Lobophyton sp.

\begin{abstract}
ABSTRAK
Karang Lunak (Octocorallia alcyonacea) merupakan hewan anggota Coelenterata yang hidup di perairan dangkal tropis dan subtropis. Karang lunak memiliki potensi cukup besar dalam menghasilkan senyawa aktif yang dapat digunakan dalam dunia farmasi. Penelitian ini bertujuan untuk menentukan adanya Aktivitas Antimikroba dari Jamur Laut Yang Berasosiasi dengan Karang Lunak Lobophytum sp terhadap bakteri bakteri Staphylococcus aureus, Eschericia coli dan jamur Candida Albicans. Hasil penelitian ini menunjukkan bahwa ekstrak dari Jamur yang berasosiasi dengan Karang Lunak Lobophytum sp memiliki Aktivitas hanya pada bakteri Staphylococcus aureus dan jamur Candida albicans, sedangkan untuk bakteri Eschericia coli tidak memiliki Aktivita Antimikroba
\end{abstract}

Kata kunci: Antimikroba, Jamur Laut, Lobophytum 


\section{PENDAHULUAN}

Indonesia memiliki sumber daya alam hayati laut yang besar, salah satu sumber daya alam tersebut adalah ekosistem terumbuh karang. Ekosistem terumbuh karang merupakan bagian dari ekosistem laut yang menjadi sumber kehidupan bagi beranekaragam biota laut. Di dalam ekosistem terumbuh karang bisa hidup lebih dari 300 jenis karang, lebih dari 200 jenis ikan dan berpuluh-puluh jenis, sponge, algae, dan biota lainnya (Arsita,2015).

Karang Lunak

(Octocorallia alcyonacea) merupakan hewan anggota Coelenterata yang hidup di perairan dangkal tropis dan subtropis. Keberadaannya diketahui berlimpah di samudera hindia mulai dari laut india (van, 2000).

Karang lunak merupakan sumber yang kaya akan senyawa bioaktif contohnya seperti, alkaloid, dan flavonoid. Hasil penelitian terakhir menyebutkan bahwa sekitar 50\% ekstrak karang lunak menunjukan sifat racun pada ikan, selain itu banyak metabolit sekunder yang dihasilkan oleh karang lunak memiliki aktifitas biologi, seperti Antifungi, dan Antimikroba (Andi,2015).

Mikroba patogen merupakan salah satu penyebab penyakit pada manusia dan makhluk hidup lainnya. Banyak usaha yang telah dilakukan untuk mengantisipasi pengaruh mikroba patogen tersebut yaitu dengan menemukan senyawa kimia yang dapat menghambat pertumbuhan dan membunuh bakteri (Juariah, 2014).

Mikroba sangat berperan dalam kehidupan sehari-hari, terdapat di udara, makanan, permukaan kulit, tangan, mulut, usus, dan pada seluruh permukaan tubuh yang terbuka dan dianggap sebagai flora normal. Mikroba terdiri dari bakteri, jamur, dan virus. Secara umum, tiap mikroba mempunyai morfologi dan struktur anatomi yang berbeda (Waluyo, 2004).

Jamur merupakan jasad eukariot. yang memiliki sel tunggal. Jamur tidak memiliki sel yang berklofil, dinding sel jamur tersusun dari kitin, dan belum ada diferensiasi jaringan. Habitat jamur terdapat pada air dan tanah. Jamur bisa hidup pada organisme laut seperti pada spons atau karang lunak (Wahyu,2010).

\section{METODOLOGI PENELITIAN}

\section{Waktu dan Tempat Penelitian}

Penelitian ini dilaksanakan pada bulan Mei 2019 sampai bulan September 2019 di Laboratorium Farmasi Lanjut Fakultas Matematika dan Ilmu Pengetahuan Alam Universitas Sam Ratulangi.

\section{Alat dan Bahan}

a. Alat

Alat yang digunakan dalam penelitian ini yaitu masker, sarung tangan, gunting, scuba diving, kantong plastik, kamera bawah laut, wadah kaca, pisau, erlenmeyer (pyrex), corong, rotary evaporator, timbangan digital, gelas ukur (pyrex), gelas kimia (pyrex), cawan petri, corong pisah (pyrex), autoklaf, pinset, spatula, pembakar spritus, magnetic stirrer, pipet tetes, mikro tub, batang pengaduk, laminar air flow,rak tabung reaksi, tabung reaksi, lemari pendingin, inkubator, cakram (paper disc), mikropipet, vial, jangka sorong, jarum ose.

b. Bahan

Bahan yang digunakan yaitu bakteri uji Staphylococcus aureus ATCC 25923, Escherichia coli ATCC 25922, jamur uji Candida albicans ATCC 1231, etanol, aquadest, etil asetat, aseton, Potato Dextro Agar,NutrientAgar,GlukosaPolypeptone, $\mathrm{MgS}$ $\mathrm{O}_{4} .7 \mathrm{H}_{2} \mathrm{O}$,Yeast Extract, $\mathrm{KH}_{2} \mathrm{PO}_{4}$, Sukrosa, Starch, Malt Extract, Ebios, larutan $\mathrm{H}_{2} \mathrm{SO}_{4}$ $1 \%$, larutan $\mathrm{NaCl} 0,9 \%$, kloramfenikol 
paperdisc, label, spidol permanen, tissue, aluminium foil, kertas saring, kapas.

\section{Pengambilan Sampel dan Persiapan Sampel}

Sampel Karang Lunak Lobophytum sp diambil dari perairan desa Tumbak kecamatan Pusomaen Minahasa Tenggara Sulawesi Utara menggunakan alat bantu (Scuba Diving), diambil kemudian dimasukan ke dalam ziper bag dan disimpan dalam cooling box berisi es batu untuk dibawah ke Laboratorium Farmasi Lanjut Fakultas Matematika dan Ilmu Pengetahuan Alam Universitas Sam Ratulangi.

\section{Isolasi dan purifikasi jamur yang berasosiasi dengan karang lunak}

Isolasi jamur dilakukan dengan cara sampel dibersihkan dengan aquades kemudian dipotong kecil-kecil menggunakan gunting dan pinset dan dimasukkan ke dalam media PDA yang telah disiapkan. Sampel ditanam di atas media PDA dengan tiga titik pusat yang berbentuk segitiga. Cawan petri yang berisi sampel ditutup dan direkatkan menggunakan parafilm, kemudian diinkubasi pada suhu ruangan selama 7x24 jam. Setelah didapatkan isolat jamur, dilakukan pemurnian dengan cara isolat jamur diinokulasikan ke media PDA yang baru, kemudian diinkubasi pada suhu ruangan selama $14 \times 24$ jam. Selanjutnya diidentifikasi morfologi secara makroskopik untuk menghasilkan isolat jamur murni.

\section{Ekstraksi}

Ekstraksi dilakukan pada campuran miselium jamur dan broth dengan menggunakan $200 \mathrm{~mL}$ aseton. Ekstraksi dilakukan dengan menggunakan shaker pada suhu ruangan dengan kecepatan $150 \mathrm{rpm}$ selama 5 menit. Selanjutnya dipisahkan antara fase air dan aseton menggunakan corong pisah dan kertas saring. Setelah didaptkan filtrat dari hasil penyaringan kemudian diuapkan dengan rotary evaporator.

\section{Fraksinasi}

Ekstrak cair dari hasil evaporasi, dimasukkan ke dalam corong pisah dan ditambahkan pelarut etil asetat sebanyak 200 $\mathrm{mL}$ setelah itu dikocok dalam corong pisah sampai homogen. Dibiarkan sampai terbentuk dua lapisan. Masing-masing lapisan ditampung pada wadah yang berbeda. Lapisan $\mathrm{H}_{2} \mathrm{O}$ (air) kemudian difraksinasi lagi menggunakan pelarut etil asetat sebanyak 200 mL. Hal ini dilakukan sebanyak tiga kali. Selanjutnya fraksi etil asetat dikumpulkan kemudian pelarut diuapkan menggunakan rotary evaporator sampai diperoleh ekstrak kasar yang akan digunakan untuk uji aktivitas antimikroba.

\section{Sterilisasi Alat}

Alat-alat yang akan digunakan dalam penelitian uji aktivitas antimikroba harus disterilkan terlebih dahulu. Alat-alat gelas disterilkan menggunakan autoklaf pada suhu $121^{\circ} \mathrm{C}$ selama \pm 15 menit pinset, gunting, dan jarum ose direndam dengan alkhohol dan dibakar dengan pembakaran di api langsung dan media disterilkan menggunakan autoklaf pada suhu $121^{\circ} \mathrm{C}$ selama 15 menit.

\section{Pembuatan Media}

\section{Media Potato Dextros Agar (PDA)}

Sebanyak 4,2 gram Potato Dextros Agar (PDA) ditambahkan air laut sampai 100 $\mathrm{mL}$ diaduk sampai homogen. Media tersebut disterilkan di dalam autoklaf pada suhu $121^{\circ} \mathrm{C}$ selama 15 menit, kemudian dipindahkan pada cawan petri dan didinginkan. Media tersebut digunakan sebagai media isolasi jamur.

\section{Media Nutrien Agar (NA)}

Sebanyak 3,36 gram Nutrien Agar ditambahkan aquades sampai $120 \mathrm{~mL}$ diaduk sampai homogen. Media tersebut 
disterilkan di dalam autoklaf pada suhu $121^{\circ} \mathrm{C}$ selama 15 menit, kemudian dipindahkan pada cawan petri dan didinginkan (Nuraina, 2015).

\section{Media Agar Miring}

Nutrien agar (NA) sebanyak 0,784 gram dilarutkan dalam $28 \mathrm{ml}$ aquades dan Potato Dextros Agar (PDA) sebanyak 0,588 gram dilarutkan dalam $14 \mathrm{~mL}$ aquades menggunakan erlenmeyer dan diaduk sampai homogen. Media tersebut disterilkan di dalam autoklaf pada suhu $121^{\circ} \mathrm{C}$ selama 15 menit, kemudian dibiarkan pada suhu ruangan sampai media memadat pada kemiringan 300. Media agar miring digunakan untuk inokulasi mikroba (Lay, 1994).

\section{Media Kultur Cair}

1. Sebanyak 2 gram glukosa, 0,5 gram polypeptone, 0,05 gram $\mathrm{MgSO}_{4} \cdot 7 \mathrm{H}_{2} \mathrm{O}$, 0,2 gram yeast extract, 0,1 gram $\mathrm{KH}_{2} \mathrm{PO}_{4}, \quad 0,1$ gram agar dilarutkan dalam $100 \mathrm{~mL}$ aquades menggunakan erlenmeyer dan diaduk sampai homogen dan disterilkan. Kemudian isolat jamur murni diinokulasikan ke dalam media pembenihan dan dishaker di dalam inkubator shaker selama $3 \times 24$ jam (Yamazaki et al., 2012).

2. Sebanyak 4,5 gram sukrosa, 4,5 gram starch, 1,5 gram extract malt, 0,45 gram ebios, 0,75 $\mathrm{KH}_{2} \mathrm{PO}_{4}, 0,075$ gram $\mathrm{MgSO}_{4}$ dilarutkan dalam $150 \mathrm{~mL}$ aquades menggunakan erlenmeyer dan diaduk sampai homogen dan disterilkan. Kemudian diinokulasikan bibit kultur dari media pembenihan dan dishaker di dalam inkubator shaker selama 7x24 jam (Yamazaki et al., 2012).

\section{Pembuatan Suspensi Mikroba Uji}

Mikroba yang telah diinokulasi diambil dengan jarum ose steril kemudian disuspensikan ke dalam tabung reaksi yang berisi $7 \mathrm{~mL}$ larutan $\mathrm{NaCl} 0.9 \%$, setelah itu divortex hingga diperoleh kekeruhan yang sama dengan larutan Mc. Farland Perlakuan yang sama dilakukan pada jamur uji (Dwyana, 2012).

\section{Pembuatan Kontrol Positif dan Kontrol Negatif}

Kontrol positif yang digunakan yaitu antibiotik kloramfenikol. Kontrol negatif yang digunakan dalam penelitian ini yaitu menggunakan metanol, dengan cara membuat larutan stok metanol dengan mengambil sebanyak $200 \mu \mathrm{l}$ metanol kemudian ditotolkan pada paper disc.

\section{Pembuatan Larutan Uji}

Dibuat larutan uji dengan cara ditimbang ekstrak kasar jamur dari spons Callyspongia aerizusa. sebanyak $1 \mathrm{mg}$, kemudian dilarutkan dalam 200ml methanol sehingga menghasilkan konsentrasi larutan uji sebesar $250 \mu \mathrm{g} / 50 \mu \mathrm{l}$ (Ortez, 2005).

\section{Pengujian Aktivitas Antimikroba}

Metode yang digunakan dalam penelitian ini yaitu metode kertas cakram (cara Kirby and Bauer). Aktivitas penghambatannya diuji terhadap Staphylococcus aureus ATCC 25923 (bakteri Gram positif), Eschrichia coli ATCC 25922 (bakteri Gram negatif) dan Candida albicans ATCC 1231 (jamur), yang digunakan sebagai mikroorganisme uji. Pada pengujian aktivitas antimikroba ini, cakram (paper disc) yang digunakan berukuran $6 \mathrm{~mm}$. Suspensi mikroba kemudian diinokulasikan ke dalam media dan dihomogenkan. Kemudian media yang telah diinokulasi mikroba dituangkan ke dalam cawan petri dan tunggu sampai media 
memadat. Masingmasing cawan petri diberi label dan nomor sampel yang sesuai. Sampel yang telah ditentukkan konsentrasinya $(250 \mu \mathrm{g} / 50 \mu \mathrm{L})$ ditotolkan pada masing-masing cakram dengan menggunakan mikropipet. Letakkan kertas cakram yang telah ditotolkan sampel uji dengan pinset kedalam cawan petri lalu diinkubasi selama 1 x 24 jam (Ortez, 2005).

\section{Pengamatan dan Pengukuran Zona Bening}

Pengamatan dilakukan setelah 1x24 jam masa inkubasi. Zona bening merupakan petunjuk kepekaan mikroba terhadap bahan antimikroba yang digunakan sebagai bahan uji yang dinyatakan dengan lebar diameter zona hambat. Diameter zona hambat diukur kemudian dikategorikan kekuatan daya antimikrobanya berdasarkan penggolongan (Vandepite, 2005).

\section{HASIL DAN PEMBAHASAN Isolasi dan Purifikasi Jamur yang Berasosiasi dengan Karang lunak}

Koloni jamur yang yang tumbuh diamati perbedaan karakteristik secara mikroskopik. Dalam penelitian ini setelah $3 \times 24$ jam, isolat jamur yang tumbuh terlihat seperti benang-benang halus yang berwarna putih. Selanjutnya isolat jamur yang tumbuh dilakukan dengan cara diinokulasikan ke media PDA yang baru dan diinokulasikan selama 14x24 jam pada suhu ruangan. Hal ini bertujuan untuk dapat memisahkan kolonikoloni jamur agar dapat menghasilkan isolat jamur yang karakteristik secara mikroskopik yang mempunyai morfologi yang sama agar dapat disebut isolat jamur murni.

\section{Kultur Cair}

Dalam penelitian ini isolat jamur dikultivasi sebanyak dua kali dengan periode yang berbeda. Kultivasi yang pertama dilakukan selama 3x24 jam untuk menghasilakn bibit kultur. Kultivasi yang kedua dilakukan selama $14 \times 24$ jam untuk menghasilkan senyawa dari bibit kultur. Kultivasi dilakukan dengan menggunakan metode shaker pada suhu $27^{\circ} \mathrm{C}$ dengan kecepatan $150 \mathrm{rpm}$, hal ini bertujuan agar semua nutrisi yang dikandung dalam medium dapat digunakan oleh jamur secara optimal sebagai bahan untuk metabolismenya sehingga senyawa antimikroba dapat dihasilkan dengan optimal.

\section{Ekstraksi dan Fraksinasi}

Setelah didapatkan hasil produksi dari kultur cair, tahap selanjutnya yang dilakukan adalah ektraksi. Hasil dari kultur cair diekstraksi dengan menggunakan pelarut aseton. Proses ekstraksi yang bertujuan untuk memisahkan atau menyari senyawa aktif yang ada di dalam sampel, sehingga adanya suatu proses pemisahan dua atau lebih komponen yang terkandung dalam sampel, oleh suatu pelarut (Suryanto, 2012).

Tujuan pemilihan metode maserasi karena merupakan metode yang paling sederhana dan sangat banyak digunakan. Cara ini sesuai, baik untuk skala kecil maupun skala industri. Sampel diekstraksi dengan cara sampel direndam dengan pelarut aseton dan diaduk menggunakan alat shaker pada suhu ruangan selam \pm 5 menit. Kemudian aseton di uapkan sehingga di peroleh fraksi air.

\section{Uji Aktivitas Antimikroba}

Dalam penelitian ini pengujian aktivitas antimikroba dari jamur yang berasosiasi dengan Karang lunak Lobophytum sp . Diuji pada Staphylococcus aureus ATCC 25923 untuk mewakili bakteri golongan Gram positif, Eschrichia coli ATCC 25922 untuk mewakili bakteri golongan Gram negatif dan Candida albicans ATCC 1231 mewakili golongan jamur. Penggunaan mikroba uji ini untuk mengetahui apakah ekstrak kasar dari jamur berasosiasi memiliki aktivitas sebagai 
antimikroba serta apakah mempunyai spektrum diperluas yaitu dapat membunuh bakteri Gram positif, Gram negatif dan jamur atau mempunyai spektrum sempit yaitu hanya dapat membunuh salah satu dari bakteri Gram positif, Gram negatif atau jamur.

Pada pengujian ini menggunakan metode difusi agar. Metode difusi dilakukan dengan cara disc diffusion (difusi cakram) yaitu kertas yang berisi agen antimikroba untuk menentukan aktivitas antimikroba. Metode difusi cakram dipilih karena memiliki kelebihan dapat digunakan untuk senyawa non polar, cepat, mudah dan sederhana (Valgas et al., 2007).

Kertas cakram yang berisi agen antimikroba diletakkan dipermukaan media agar yang sudah diinokulasikan mikroorganisme uji. Agen antimikroba akan berdifusi dari kertas cakram menuju ke media agar dan melakukan penghambatan pada pertumbuhan mikroorganisme yang diuji. Area jernih mengindikasikan adanya hambatan pertumbuhan mikroorganisme oleh agen antimikroba pada permukaan media agar. Hasil pengukuran diameter zona hambat dari ekstrak jamur yang diisolasi dari karang lunak Lobophytum sp dilakukan hanya pada satu konsentrasi yaitu konsentrasi $250 \mu \mathrm{g}$. Dalam pengujian ini digunakan kontrol positif dan negatif. Penggunaan kontrol positif berfungsi sebagai kontrol dari zat uji, dengan membandingkan diameter daerah hambat yang terbentuk (Dwijendra, 2014).

Tujuan penggunaan kontrol negatif agar dapat mengetahui ada tidaknya pengaruh pelarut terhadap pertumbuhan mikroba uji, sehingga dapat dipastiikan bahwa aktivitas yang ditunjukkan oleh ekstrak ialah senyawa yang terkandung dalam sampel bukan berasal dari pelarut yang digunakan. Dalam penelitian ini, pelarut metanol digunakan sebagai kontrol negatif.
Dari hasil yang diperoleh bahwa menunjukkan bahwa kontrol negatif tidak terbentuk zona hambat. Diameter zona hambat diukur secara horizontal dan vertikal menggunakan jangka sorong. Rata-rata hasil pengukuran diameter zona hambat disajikan pada Table 1.

Tabel 1. Pengukuran zona hambat ekstrak Lobophytum $\mathrm{sp}$

\begin{tabular}{llcc}
\hline \multirow{2}{*}{ perlakuan } & \multicolumn{2}{l}{$\begin{array}{l}\text { Rata-rata } \\
\text { hambat }(\mathrm{mm})\end{array}$} & diameter \\
\cline { 2 - 4 } & SA & EC & CA \\
\hline Ekstrak & 6,33 & 0,00 & 10.66 \\
$\begin{array}{l}\text { Etil asetat } \\
\text { kontrol } \\
\text { positif }\end{array}$ & 26 & 21 & 19 \\
\hline $\begin{array}{l}\text { kontrol } \\
\text { negatif }\end{array}$ & 0,00 & 0,00 & 0,00 \\
\hline
\end{tabular}

Penilaian zona hambat di golongkan berdasarkan kategori diameter zona hambat di mana diameter $\leq 5 \mathrm{~mm}$ berarti daya hambatnya lemah, jika 6-10 $\mathrm{mm}$ berarti kekuatan daya hambatnya sedang,jika 11-20 $\mathrm{mm}$ berarti daya hambatnya kuat, dan jika di atas $21 \mathrm{~mm}$ berarti daya hambatnya sangat kuat (susanto,2012).

Dari hasil fraksi etil asetat, zona bening yang terbentuk di kategorikan sedang pada jamur Candida albicans dengan hasil 10,66 mm sendangkan pada Staphylococcus aureus hasilnya $6,33 \mathrm{~mm}$ yang bisa dikatakan sedang, dan pada Escherichia coli tidak ada aktivitas apa-apa hanya terbentuk kertas cakram saja. Jadi ini menujukan bahwa jamur yang berasosiasi dengan karang lunak lobophytum $s p$ hanya memiliki aktifitas antimikroba pada Staphylococcus aureus dan Candida albicans tetapi memiliki aktivitas yang sedang. 
Dari hasil menunjukkan diameter zona hambat dari kontrol positif pada bakteri Staphylococcus aureus yang di kategori kuat yaitu $26 \mathrm{~mm}$, Escherichia coli $21 \mathrm{~mm}$ termasuk kategori kuat, dan untuk jamur Candida albicans yaitu $19 \mathrm{~mm}$ termasuk kategori kuat Kontrol positif yang di gunakan adalah antibiotik kloramfenikol. Kloramfenikol di gunakan untuk melawan infeksi yang di sebabkan oleh beberapa jenis bakteri gram positif dan gram negatif. Kloramfenikol mempunyai khasiat bakterisid (Sumardjo,2009).

Dari hasil yang diperoleh menunjukkan bahwa ekstrak dari karang lunak dan fraksi etil menghasilkan zona bening berdiameter sedang yang mampu menghambat pertumbuhan mikroba uji Staphylococcus aureus, dan jamur Candida albicans. Sedangkan untuk Escherichia coli tidak adanya kepekaan aktivitas antimikroba untuk itu tidak terdapat zona bening pada saat pengujian.

\section{KESIMPULAN}

Berdasarkan hasil penelitian yang telah dilakukan dapat disimpulkan bahwa ekstrak Karang lunak Lobophytum hanya memiliki aktivitas antimikroba pada bakteri Staphylococcus aureus dan jamur Candida albicans tergolong aktivitas yang sedang. Sedangkan untuk Escherichia coli tidak adanya kepekaan aktivitas antimikroba untuk itu tidak terdapat zona bening pada saat pengujian di lakukan.

\section{SARAN}

Perlu dilakukan penelitian lebih lanjut terhadap Karang lunak Lobophytum $s p$ dengan metode pengujian yang berbeda dan uji aktivitas lainnya agar dapat mengetahui manfaat lain selain aktivitas antimikroba.

\section{DAFTAR PUSTAKA}

Arsita,A,.2015.Uji efektifitas Antibakteri ekstrak etanol spons laut (porifera:Demospongie) terhadap bakteri staphylococcus aureus dan escherchia coli.jurnal UGD.2(3)

Andifatmawati.2015.Uji aktifitas ekstrak karang lunak sareophyton $s p$ terhadap staphylococcusaureus.Jurnal analis.12(13)

Dwijendra, I. M. 2014. Aktivitas Antibakteri dan Karakterisasi Senyawa Fraksi Spons Lamellodysidea herbacea yang Diperoleh dari Teluk Manado [skripsi]. Program Studi Farmasi FMIPA Universitas Sam Ratulangi, Manado.

Dwyana, Z dan Johanes E. 2012. Uji Efektivitas Ekstrak Kasar Alga Merah Eucheuma Cottoni Sebagai Antibakteri Terhadap Bakteri Patogen. [Skripsi]. Program Studi Biologi Universitas Hasanudin, Makassar.

Juariah, S., Suryanto, D., dan Jamilah, I. 2014. Aktivitas Antibakteri Spesies Asterias Forbesii terhadap Beberapa Jenis Bakteri Patogen. Jurnal Berkala Perikanan Terubuk . 42 ( 2 ) : 37 - 50.

Khairani, M. 2009. Pengaruh Sediaan Teh ( Camellia sinensis (L) O. Kuntze ) dan Madu Terhadap Bakteri Salmonella typhi Schroeter dan Staphylococcus aureus Rosenbach . [Skripsi]. Universita s Andalas. Padang

Ortez, J. H. 2005. Disk Diffusion testing in manual of antimicrobial susceptibility testing. Marie B. Coyle (Coord. Ed). American society for Microbiology, America.

Suryanto, E. 2012. Fitokimia Antioksidan. Putra Media Nusantara, Surabaya. 
PHARMACONJurnal IImiah Farmasi - UNSRAT Vol. 9 No. 1 FEBRUARI 2020 ISSN 2302 - 2493

Venn AA, Loram JE, Douglas AE. 2008.

Photosynthetic symbioses in animals.

Journal of Experimental Botany 59:

1069-1080. 